\title{
IMPLEMENTASI PENDEKATAN INTEGRATED SYSTEM DALAM MENINGKATKAN MINAT DAN PRESTASI BELAJAR BAHASA ARAB SISWA KELAS XI DI MA NU MIFTAHUL ULUM MARGASARI-TEGAL
}

\author{
Akhmad Aufa Syukron \\ UIN Sunan Kalijaga Yogyakarta \\ akhmadaufasyukron88@gmail.com
}

\begin{abstract}
This study aims to determine the concept of the Integrated System approach, and the extent of the contribution of the Integrated System Approach to learning interest and student learning achievement in learning Arabic. The approach used in the study is classroom action research (PTK).Subjects in this study were students of class XI MA NU Miftahul Ulum Margasari.The results of this study indicate that in the preaction interest of students was less interested as much as $40 \%$, then after the implementation of the action in the first cycle increased to be quite interested as much as $53.30 \%$ (up 13.3\%), in the second cycle increased to $75 \%$ Interest (up by $21.7 \%$ ), and in the third cycle experienced a degree of interest in the Interest category but the percentage increased to $78.30 \%$ (up $3.3 \%$ ). Based on Student Interest Questionnaire, from the average score of positive and negative criteria 33 items ( 25 positive items and 8 negative items) that have been obtained, the combined average score is (positive criteria + negative criteria $)=(22.82+2,79=25.61) .25 .61$ is a combined average of positive and negative criteria, if it is reported to be $77.6 \%$, the interest in learning Arabic in class IX students is strong (interested) as much as $77.6 \%$. Based on the results of the tests, from the first, second and third cycles the value of Arabic subjects in class XI Science and Social Sciences was above the KKM average, indicating that student learning achievement increased by an average of 75.7 above the KKM score of 67 .
\end{abstract}

Keywords: integrated system approach, classroom action research, learning arabic

Abstrak: Penelitian ini bertujuan untuk mengetahui konsep pendekatan Integrated System, dan sejauh mana kontribusi Pendekatan Integrated System terhadap minat belajar dan prestasi belajar siswa dalam pembelajaran bahasa Arab.Pendekatan yang digunakandalampenelitian adalah penelitian tindakan kelas (PTK).Subjek dalam penelitian ini adalah siswa kelas XI MA NU Miftahul Ulum Margasari. Hasil penelitian ini menunjukkan bahwa pada pra tindakan, siswa kurang berminat sebanyak 40\%, kemudian setelah pelaksanaan tindakan pada siklus I meningkat menjadi cukup berminat 
sebanyak 53,30\% (naik 13,3\%), pada siklus II meningkat menjadi Berminat 75\% (naik 21,7\%), dan pada siklus III mengalami keajegan degan kategori berminat namun prosentasenya meningkat menjadi 78,30\% (naik 3,3\%). Berdasarkan angket minat siswa, dari skor rata-rata kriteria positif dan negatif 33 item (25 item positif dan 8 item negatif) yang telah diperoleh, maka skor rata-rata gabungannya adalah (kriteria positif +kriteria negatif) $=(22,82+2,79=25,61) \cdot 25,61$ adalah rata-rata gabungan dari kriteria positif dan negatif, jika diprosentasikan menjadi 77,6\%, maka minat belajar bahasa Arab siswa kelas IX Kuat (Berminat)sebanyak 77,6\%. Berdasarkan hasil tes, dari siklus I, II dan III nilai mata pelajaran bahasa Arab siswa kelas XI IPA dan IPS di atas rata-rata KKM, menunjukkan bahwa prestasi belajar siswa meningkat dengan rata-rata 75,7 di atas nilai KKM 67.

Kata-kata kunci:Pendekatan Integrated System, Penelitian Tindakan Kelas, Pembelajaran bahasa Arab

\section{A. Pendahuluan}

Dalam dunia pendidikan, peran pendidik sangatlah penting. Kegiatan pembelajaran tidak akan berjalan tanpa adanya pendidik (guru). Menurut Undangundang, Guru adalah pendidik professional dengan tugas utama mendidik, mengajar, membimbing, mengarahkan, melatih, menilai, dan mengevaluasi peserta didik. ${ }^{1}$ Guru juga harus berkompeten artinya menguasai kemampuan dalam mendidik, memahamkan dan mentranformasikan ilmu kepada peserta didik.Oleh karena itu, pendidik harus tahu metodologi dan strategi pembelajaran supaya tercapainya tujuan pembelajaran.Khususnya dalam pembelajaran bahasa Arab. Guru bahasa Arab harus dapat mengantarkan peserta didiknya mencapai suatu tujuan pembelajaran yaitu berkomunikasi dengan bahasa Arab. Namun, kadang terkendala dengan minat peserta didik dalam belajar bahasa Arab, apalagi peserta didik yang belum mengenal sama sekali bahasa Arab.

Pada dasarnya menumbuhkan minat belajar peserta didik sebetulnya tidak terlalu sulit. Dengan mengenali apa yang peserta didik (siswa) sukai, maka minat belajarpun meningkat, kuncinya adalah mengetahui apa yang dapat membuat siswa tertarik dan ingin belajar. Dengan guru mengetahui apa yang siswa sukai, maka pembelajaran akan lebih mudah dan minat siswa untuk belajar bahasa Arab akan mulai terlihat. Apabila minat belajar siswa untuk mempelajari bahasa Arab semakin baik maka semakin baik pula prestasi belajar bahasa Arab siswa. Akan tetapi, Guru juga harus menggunakan berbagai pendekatan dan metode-metode dalam proses pembelajaran bahasa Arab, agar tepat sasaran dan tercapainya suatu tujuan pembelajaran. Pembelajaran bahasa Arab sendiri dikenal dengan beberapa pendekatan, metode, teknik dan strategi.Dan dari pendekatan muncul beberapa metode, dan dari metode muncul beberapa teknik

1 Undang-Undang No. 14 Tahun 2005 Tentang Pendidik dan Dosen, Pasal 1 ayat 1. 
atau strategi. Hal ini adalah suatu cara pendidik agar mencapai tujuan pembelajaran itu sendiri. Approach atau pendekatan itu berarti susatu yang diyakini tetapi tidak harus mesti dibuktikan.Pendekatan itu sendiri terdiri atas serangkaian asumsi mengenai hakekat bahasa dan pengajaran bahasa serta belajar bahasa. ${ }^{2}$

Dapat disimpukan bahwa pendekatan adalah asumsi berkenaan dengan hakekat belajar mengajar, metode adalah cara/rencana menyeluruh yang berkenaan dengan penyajian materi, sedangkan teknik ini lebih spesifik dan merupakan implementasi daripada metode.Salah satu penunjang tercapainya tujuan pengajaran adalah menerapkan pendekatan yang baik yang digunakan serta penempatan metode yang tepat.Semakin baik dan tepat metode, makin efektif pula pencapaian tujuan. Drs. Abu Tauhid, M.Sc, mengatakan bahwa:

"Hubungan antara metode dan tujuan pendidikan bisa merupakan hubungan sebab akibat, artinya metode pendidikan yang digunakan baik dan tepat, maka akibatnya tujuan yang dirumuskannya juga bisa kemungkinan tercapai gemilan". ${ }^{3}$

Dalam pembelajaran bahasa Arab mengenal beberapa pendekatan. Salah satunya adalah pendekatan All In One System (All In One System Approach), pendekatan ini dikenal dengan Nazhariyyatul Wahdah pendekatan ini memandang bahwa bahasa merupakan satu kesatuan yang utuh, tidak terpisah-pisahkan, pendekatan ini juga dikenal sebagai pendekatan integrated system, pendekatan integrated system dapat dimaksimalkan dengan metode aural oralmetodh(الطريقة سمعية شففوية) dan direct metodh (الطريقة مباشرة)yaitu denganmenimbulkan daya tangkap pelajar terhadap bahasa yang didengarnya dari ucapan orang lain (aural), dan agar peserta didik (murid) dapat menggunakan bahasa secara lisan dalam pergaulan (oral).

Pendekatan Integrated System banyak dimaksimalkan dengan metode auraloral.Metode ini memfokuskan pada aural dan oral, memfokuskan dengan apa yang didengar dan apa yang diucapkan. Metode ini melatih peserta didik untuk menghafal kosakata agar menjadi terbiasa dalam ujaran.Sedangkan tulisan adalah interpretasi dari ujaran. Dalam metode ini peserta didik akan aktif dalam kelas, karena peserta didik dituntut untuk terus merespon stimulus pendidik. Asumsi inidiperkuat dengan adanya faktor kebiasaan, karena suatu perilaku akanmenjadi kebiasaan apabila diulang berkali-kali, begitu pula dengan pengajaran bahasa harus dilakukan dengan teknik pengulangan atau repetisi. ${ }^{4}$

Minat belajar dan bagaimana cara guru mengajar sangatlah penting. Apabila minat belajarnya rendah prestasinya juga rendah.Seperti yang terjadi di MA NU Miftahul Ulum Margasari Tegal rendahnya minat belajar bahasa Arab peserta didik

2 Mulyanto Sumardi, Pengajaran bahasa Asing: sebuah tinjanan dari segi metodologis, Cet. I,(Jakarta: Bulan Bintang, 1974), hlm. 11-12.

3 Abu Tauhid, Beberapa Aspek Pendidikan Islam, (Yogyakarta: FTY, 1990), hlm. 72-73

4 Radliyah Zaenuddin, et. al., Metodologi dan Strategi Alternatif Pembelajaran Bahasa Arab, (Yogyakarta: Pustaka Rihlah Group, 2005), hlm. 41 
terhadap mata pelajaran bahasa Arab.Menandakan bahwa pendekatan-pendekatan dan metode yang digunakan kurang menarik.Hal ini dibuktikan berdasarkan hasil observasi pra penelitian yang diperoleh yaitu $40 \%$.

Dari fakta tersebut dapat diduga penyebab mengapa minat belajar peserta didik rendah, antara lain sebagai berikut: guru masih menggunakan metode konvensional yaitu dengan metode ceramah, siswa kurang memahami konsep pengajaran bahasa Arab, mind set (pola pikir) peserta didik yang menganggap bahwa bahasa Arab adalah pelajaran yang susah dipelajari daripada bahasa Inggris dan mereka beranggapan bahwa bahasa Arab merupakan bahasa yang tidak mendunia, lain halnya bahasa Inggris, minat baca peserta didik terhadap buku teks Arab juga rendah, peserta didik kurang berani bertanya pada saat proses belajar mengajar berlangsung. Berdasarkan latar belakang tersebut, penelitian ini bertujuan untuk: (1) Mengetahui konsep pendekatan Integrated System dalam pembelajaran bahasa arab di MA NU Miftahul Ulum Tegal; (2)Mengetahuisejauhmana pengaruh/kontribusi Pendekatan Integrated System terhadap minat siswa dalam pembelajaran bahasa Arab di MA NU Miftahul Ulum Tegal; (3) Mengetahui sejauh mana pengaruh/kontribusi Integrated System terhadap prestasi belajar dalam pembelajaran bahasa Arab di MA NU Miftahul Ulum Tegal.

\section{B. Landasan Teori}

\section{Konsep Pendekatan Integreted System}

Dalam pembelajaran bahasa Arab ada tiga istilah yang perlu dipahami secara cermat dalam upaya mencari kemungkinan perbaikan cara pembelajaran bahasa Arab untuk memperoleh hasil maksimal yang ingin dicapai, yakni approach (المدخل), metode dan teknik. 'Approach (المدخل), dalam bahasa Arab adalah"seperangkat asumsi mengeani hakekat belajar mengajar bahasa. Sifatnya aksiomatik (filosofis)"'

Pada bulan Maret 1904 untuk pertama kalinya terbit sebuah buku yang berjudul How to Teach a Foreign Language yang pada saat itu dianggap sangat representatif dipergunakan untuk pengajaran bahasa asing. Buku itu sudah mulai membahas beberapa cara mengajarkan bahasa asing serta kemampuan-kemampuan bahasa pada saat itu mulai ditawarkan, yaitu kemampuan menyimak, membaca, mengekspresikan ide, dan menulis. Akan tetapi, buku tersebut hanya sebatas menawarkan teknik pengajaran bahasa Inggris dan Latin, tidak menyentuh sama sekali pengajaran bahasa Arab. ${ }^{7}$

Di Indonesia, pada permulaan abad ke-20, pengajaran bahasa Arab terintegrasi dengan pembaruan pendidikan Islam yang bertumpu pada penerapan sistem klasikal,

5 Wa Muna, Metodologi Pembelajaran Bahasa Arab, Cet. I, (Yogyakarta: Teras, 2011), hlm. 13

6 Azhar Arsyad, Bahasa Arab dan Metode Pengajaran, (Yogyakarta: Pustaka Pelajar, 2004),hlm. 19

7 Muhammad Rusydi Rasyid, "ALL IN ONE SYSTEM (Pendekatan dan Prinsip Psikologis Pengajaran Bahasa Arab Terintegrasi)”, LENTERA PENDIDIKAN, Vol. 12, No. 1 Juni 2009, hlm. 34 
kurikulum, penjenjangan pendidikan dan pemberian syahadah (ijazah) yang dianggap sangat perlu dan mutlak adanya.Dari sinilah sistem pengajaran bahasa Arab yang semula diajar- kan di mesjid, langgar, dan rumah kiai ditransfer ke kelas, dan pada perkembangan selanjutnya diupayakan penyederhanaan cara mengajarkan bahasa Arab terhadap para peserta didik dalam artian menerapkan metode pengajaran bahasa asing dalam pengajaran bahasa Arab. Hal ini dimaksudkan untuk menciptakan perasaan senang dan ketertarikan dalam mempelajari bahasa Arab.Selain itu, juga dimaksudkan agar kesan sulit dan angker mempelajari bahasa sedapat mungkin dihilangkan atau diminimalkan. Selanjutnya, munculah metode tarjamah, gramatika, direct method dan disusul dengan metode gado-gado (eklektik) dalam pengajaran bahasa Arab di Indonesia.

Dalam pengajaran bahasa asing secara separate (terpisah-pisah dari masingmasing bagian) terdapat beberapa kelemahan bagi para guru dan peserta didik. Di samping mengajarkan materi kebahasaan itu sendiri, terget penyelesaian maddah harus rampung sebelum memasuki ujian semester karena kurikulum menghendaki demikian.Atas dasar tersebut, Mukti Ali pada saat itu menduduki jabatan Menteri Agama RI mengatakan bahwa penguasaan bahasa Arab sebagai bahasa yang penting dikuasai oleh mahapeserta didik IAIN masih sangat lemah.Ia lalu mengusulkan penerapan All in One System atau Integrated System sebagai suatu pendekatan dalam pengajaran bahasaArab.

All in One System sebagai suatu pendekatan dalam pengajaran bahasa Arab merupakan gagasan A. Mukti Ali yang pada waktu itumenjabat sebagai Menteri Agama RI. Ia berpendapat bahwa pengajaran bahasa Arab itu harus diusahakan untuk menekankan keaktifan belajar pada peserta didik lebih besar. Untuk merealisasikan ide pengajaran bahasa Arab dengan menggunakan pendekatan All in One System pada tingkat IAIN, maka dibentuklah lembaga bahasa yang dilengkapi dengan laboratorium bahasa (language laboratory). Dalam penerapan pendekatan All in One System, pengajaran bahasa dipisahkan dari fakultas dan diberi penjenjangan (level) berupa tingkat elementary, intermediate, dan advance. Pada tahap selanjutnya, pendekatan All in One System itu diterapkan pula pada tingkat sekolah lanjutan pertama (Madrasah Tsanawiyah) dan sekolah lanjutan tingkat menengah (Madrasah Aliyah). ${ }^{8}$

Dalam bahasa Inggris sistem terpadu dikenal dengan integrated system atau all in one system. Pada system ini bahasa dipandang sebagai sesuatu yang utuh, dan saling berhubungan, bukan sebagai bagian yang terpisah-pisah. Oleh karena itu, hanya ada satu mata pelajaran yaitu bahasa arab, satu buku teks, satu evaluasi, dan satu nilai hasil belajar. ${ }^{9}$ All In One System (Nazhariyyatul Wahdah) atau integrated system memandang bahasa sebagai bahasa, bahwa bahasa merupakan alat komunikasi antara manusia, hal ini merupakan suatu keutuhan dan kebulatan, kait mengait atau saling berhubungan.

8 Radhial-Hafid,PengembanganMateridanMetodePengajaranBahasaArab, (Ujungpandang: Berkah, 1993), hlm. 12.

9 Ibid., hlm. 119 
Dalam kesusasteraan klasik islam, teori ini pernah diperkenalkan oleh Abul Abbas (826-898) dalam kitabnya Al-kamil. Teori wahdah menurutnya tidak membenarkan pengkhususan jam-jam pelajaran khusus untuk suatu cabang ilmu bahasa. ${ }^{10}$ Dan menurut Gilkey dalam penelitiannya menyatakan bahwa: ${ }^{11}$

"System integration is defined in engineering as the process of bringing together the component sub-systems into one system (an aggregation of subsystems cooperating so that the system is able to deliver the overarching functionality) and ensuring that the subsystems function together as a system".

Maksud dari pernyataan tersebut adalah "Integrasi sistem didefinisikan dalam rekayasa sebagai proses menyatukan sub-sistem komponen ke dalam satu sistem (agregasi dari subsistem yang bekerja sama sehingga sistem mampu memberikan fungsi menyeluruh) dan memastikan bahwa fungsi subsistem bersama sebagai suatu sistem".

Prof. DR. H. Mahmud Yunus dalam Wa Muna, mengemukakan bahwa dalam mengajarkan Bahasa Arab ada dua teori yakni teori kesatuan (نظرية الوحدة) dan teori bagian-bagian (نظرية الفروع). ${ }^{12}$ Drs. H. Moh. Matsna HS, MA dalam Wa Muna, mengatakan bahwa: dalam pengajaran Bahasa Arab dikenal adanya dua teori (sistem) pengajaran yakni Nazhariyatul Wihdah (all in one system), yaitu sistem yang memandang bahwa bahasa adalah satu kesatuan yang utuh tidak terpisah-pisah, dan Nazhariyatul Furu' yaitu teori yang memandang bahwa bahasa terdiri dari beberapa cabang-cabang. ${ }^{13}$ Menurut Prof. H. Abuddin Nata, M.A dalam bidang Bahasa Arab, terdapat metode dan pendekatan Thariqah al-Mubasyarah/ Direct Methode (Metode Langsung) dengan pendekatan all in one system, yakni semua aspek ilmu Bahasa Arab: nahwu, Sharaf, dan balaghah diajarkan secara integrated dan sekaligus dipraktikan. ${ }^{14}$

Dari dua pendapat di atas diketahui bahwa dalam teori pembelajaran Bahasa Arab dikenal dua system pembelajaran. Teori pertama memandang bahwa Bahasa Arab berhubungan erat antara lain, dan bukan dibagi atas beberapa bagian. Dan teori yang kedua memandang bahwa Bahasa Arab terdiri dari beberapa bagian (bercabang-cabang).Dari pengertian oleh Drs. H. Moh.Matsna HS, MA tentang Nazhariyatul Wihdah (all in one system) di atas all in one system juga disebut dengan Integrated System.Integrated System berasal dari dua kata "integrated" dan "system".

10 Busyairi Madjidi, Metodologi Pengajaran Bahasa Arab Penerapan Audio Lingual Method dalam All In One System. (Yogyakarta: Sumbangsih Offset, 1994), hlm.10

11 Herbert T Gilkey, "New Air Heating Methods", New methods of heating buildings: a research correlation conference conducted by the Building Research Institute, Division of Engineering and Industrial Research, as one of the programs of the BRI fall conferences, November 1959., (Washington: National Research Council (U.S.). Building Research Institute, 1960), p. 60.

12 Wa Muna, Metodologi Pembelajaran Bahasa Arab.....,hlm. 18

13 Ibid.,hlm. 18

14 Abuddin Nata, Studi Islam Komprehensif, Cet. Ke-I, (Jakarta: Kencana, 2011), hlm. 221 
Dalam kamus Bahasa Inggris kata "integrated” artinya yang digabungkan ${ }^{15}$, dan kata "system" artinya cara, susunan, sistim. ${ }^{16}$

Berdasarkan teori-teori di atas dapat penulis simpulkan bahwa all in one system atau integrated system ini adalah sistem atau susunan yang digabungkan menjadi satu kesatuan yang utuh tidak terpisah-pisahkan dan pembelajaran bahasa Arab berhubungan erat dengan yang lainnya bukan dibagi atas beberapa bagian.

\section{Konsep Minat Belajar}

Minat (interest); adalah kecenderungan seseorang untuk melakukan sesuatu perbuatan.Misalnya minat untuk mempelajari atau melakukan sesuatu. ${ }^{17} \mathrm{Ibrahim}$ Bafadal menyatakan, bahwa minat atau interest dapat dikelompokan sebagai sifat atau sikap (traits or attitude) yang memiliki kecenderungan-kecenderungan atau tendesi tertentu, minat dapat merepresentasikan tindakan-tindakan (represent motives), minat bukan pembawaan namun dapat diusahakan, dipelajari dan dikembangkan. ${ }^{18}$ Hurlock menjelaskan minat merupakan sumber motivasi yang mendorong orang untuk melakukan apa yang mereka inginkan bila mereka bebas memilih. Bila mereka melihat bahwa suatu sesuatu akan menguntungkan, mereka merasa berminat, hal ini kemudian mendatangkan kepuasan. Bila kepuasan berkurang minat pun berkurang. ${ }^{19}$

Berdasarkan uraian konsep di atas maka dapat penulis simpulkan bahwa minat belajar adalah kecenderungan seseorang (siswa) untuk melakukan sesuatu perbuatan menyebabkan menaruh perhatian terhadap kegiatan belajar, sehingga dapat menyebabkan perubahan pengetahuan, keterampilan dan perilaku.

\section{Metode Penelitian}

Jenis penelitian ini adalah penelitian tindakan kelas (PTK).PTK ini cocok digunakan karena penelitian ini difokuskan pada permasalahan pembelajaran yang timbul dalam kelas untuk memperbaiki pembelajaran dan meningkatkan proses belajar mengajar yang lebih efektif. Melalui PTK masalah-masalah pendidikan dan pembelajaran dapat dikaji, ditingkatkan, dan dituntaskan sehingga proses pendidikan dan pembelajaran yang inovatif dan hasil belajar yang optimal dapat diwujudkan secara sistematis. ${ }^{20}$

15 Brilliant timoty dan Hasan Fadly, Kamus Lengkap Inggris-Indonesia Indonesia-Inggris, (Jakarta: Grafika Mulia), hlm. 159

16 Ibid.,hlm. 284

17 H. E. Mulyasa, Pengembangan Implementasi Kurikulum 2013, Cet. Ke-5,(Bandung: PT Remaja Rosdakarya, 2014), hlm. 68

18 Ibrahim Bafadal, Pengelolaan Perpustakaan Sekolah, (Jakarta: Bumi Aksara, 2006), hlm. 191

19 Hurlock, Perkembangan Anak, Jilid II, Penerjemah: Meitasari Tjandrasa, (Jakarta: Erlangga, 1990), hlm. 114

20 Mansur Muslich, Melaksanakan PTK Itu Mudah, (Jakarta: Bumi Aksara, 2009), hlm. 6 
Penelitian Tindakan Kelas adalah proses investigasi terkendaliuntukmenemukan dan memecahkan masalah pembelajaran di kelas, proses pemecahan masalah ini dilakukan secara bersiklus dengan tujuan untuk meningkatkan kualitas proses hasil pembelajaran di kelas tertentu.

\section{Pembahasan}

Pada kegiatan pembelajaran bahasa Arab di MA NU Miftahul Ulum Margasari, penerapan pendekatan Integrated System tidak lepas dari asas pendekatan Integrated System, yaitu memandang bahasa sebagai satu kesatuan yang utuh (integrated) bukan suatu sistem yang terpisah (separated). Keterampilan berbahasa seperti alistima' (keterampilan mendengarkan), al-kalam (berbicara), al-qira'ah(keterampilan membaca), dan al-kitabah (keterampilan menulis) tergabung dalam satu kesatuan bahasa.

\section{Gambar II. Perbedaan Integrated System dengan Separated System}
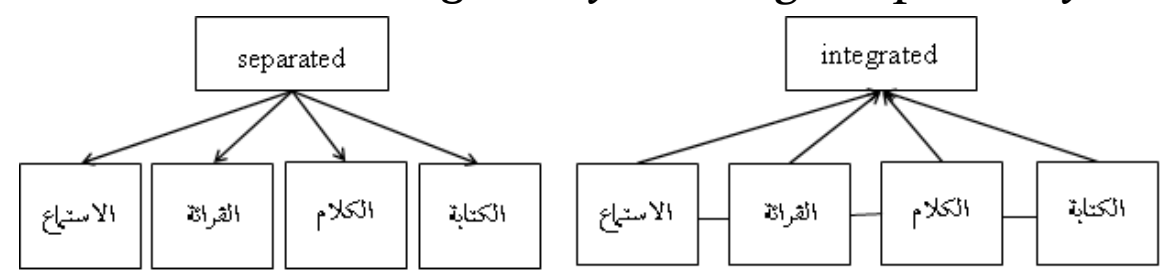

Pendekatan Integrated System menggunakan metode langsung atau metode Aural-Oral (dengar ucap). Penerapan pendekatan Integrated System di MA NU Miftahul Ulum Margasari menggunakan metode Aural-Oral,pendekatan ini mengandaikan bahwa bahasa adalah apa yang didengar dan diucapkan, bukan simbol, sedangkan tulisan hanyalah representasi dari ujaran. Dari asumsi ini dapat dikatakan bahwa bahasa adalah ujaran.Pembelajaran bahasa harus dimulai dengan mendengarkan bunyi-bunyi bahasa yang berbentuk kata dan kalimat.dimana guru bahasa Arab menyampaikan materi pada buku teks bahasa Arab kelas XI dan tidak memisahkan pada setiap keterampilan bahasa akan tetapi menggabungkan (integrated) pada setiap materi, kemudian mulai menyampaikan materi dengan metode Aural-Oral.

\section{Pra Tindakan}

Sebelum melaksanakan penelitian, untuk mengetahui kemampuan siswa, peneliti mengobservasi pembelajaran bahasa Arab siswa di Kelas XI IPA dan XI IPS pada hari Jum'at, 22 Februari 2019 dengan total pemerolehan $\left(\sum x=24\right)$, jumlah skor maksimal $\mathrm{N}=60$. Diperoleh hasil prosentase observasi pra tindakan siswa adalah 40 $\%$, maka minat siswa tergolong Kurang Berminat.peneliti juga mengobservasi guru bahasa Arab di dalam kelas, diperoleh hasil observasi pra tindakan sebagai berikut:

1) Keterampilan membuka pelajaran: Guru cukup baik dalam menarik perhatian siswa, membuat apersepsi, menyampaikan topik/ tujuan pembelajaran walaupun kondisi kurang kondusif siswa cenderung ramai, dan juga tidak memberi pre tes untuk materi yang akan disampaikan. 
2) Ketrampilan menjelaskan materi: Guru cukup jelas dalam menjelaskan materi, penggunaan contoh, penekanan hal penting, akan tetapi kurang dalam penggunaan pendekatan yang tepat, metode dan media secara tepat dan kurang kesesuaian antara materi dan media pembelajaran

3) Interaksi Pembelajaran: Guru mendorong siswa aktif, dan juga mengelola kelas akan tetapi tidak memberi bantuan siswa yang mengalami kesulitan belajar

4) Keterampilan bertanya: Guru bertanya secara menyebar kepada siswa dan memberikan waktu berfikir untuk menjawab akan tetapi tidak memberi kesempatan giliran kepada siswa lain untuk menjawab

5) Keterampilan memberi penguatan: Guru cenderung pada penguatan verbal (ucapan-ucapan) saja tanpa memberi penguatan non verbal (praktis)

6) Keterampilan menggunakan waktu: Guru menggunakan waktu selang dan memanfaatkan waktu secara efektif, akan tetapi tidak menggunakan waktu secara proporsional dan tidak memulai dan mengakhiri pelajaran sesuai jadwal.

7) Keterampilan menutup pelajaran: Guru tidak meninjau ulang isi materi pada saat menutup pelajaran.

Melihat hasil dari observasi guru maupun siswa dalam pembelajaran bahasa Arab, peneliti mulai memikirkan desain pembelajaran yang digunakan pada minggu berikutnya untuk pelaksanaan penelitian yang dimulai dengan siklus pertama. Hal-hal yang menyangkut penentuan langkah dan desain pembelajaran yang akan diputuskan, peneliti berkonsultasi langsung dengan kolaborator atau guru mata pelajaran bahasa Arab di MA NU Miftahul Ulum Margasari agar dapat menentukan langkah yang tepat.

Mata pelajaran bahasa Arab di MA NU Miftahul Ulum Margasasari menentukan nilai standard minimal kompetensi siswa atau KKM (Kriteria Ketuntasan Minimal) sebesar 67.KKM ini ditentukan berdasarkan beberapa variabel-variabel di antaranya intake siswa, tingkat kesukaran materi atau kompleksitas, serta daya dukung.Analisis penilaian peningkatan prestasi belajar siswa mengacu pada KKM, sehingga penelitian ini diharapkan mampu menjembatani antara teoritis dan praktis.Pembelajaran bahasa Arab melalui pendekatan Integrated System dapat mempermudah siswa meningkatkan minat dan prestasi belajar siswa karena semua aspek-aspek dalam bahasa Arab menjadi satu kesatuan yang utuh.

Penelitian Tindakan Kelas (PTK) tentang peningkatan minat belajar dan prestasi belajar siswa dalam pembelajaran bahasa Arab dilaksanakan di kelas XI IPA (13 siswa) dan XI IPS (20 siswa) dengan jumlah 33 siswa. Jangka waktu penelitian berjalan selama 2 bulan dari sejak persiapan perangkat pembelajaran, materi, instrument penelitian serta pembuatan tes. Pelaksanaan penelitian PTK dimulai dari tanggal 22 Februari 2019. 


\section{Pelaksanaan Tindakan Siklus I}

a. Perencanaan

Pada tahap perencanaan, peneliti telah mempersiapkan perangkat pembelajaran yang terdiri atas Rencana Pelaksanaan Pembelajaran (RPP) آمال المراهقين والصحة, lembar observasi berupa minat berikut pedoman penskoran tes penampilan pada akhir siklus untuk mengetahui ukuran kemampuan siswa dan peningkatan hasil yang mungkin dialami, serta menyiapkan media pembelajaran yang terdiri dari file presentasi materi bahasa Arab, sebelum memulai pelajaran peneliti memberikan pre test pada materi آمال المراهقين والصحة dan pada akhir pembelajaran bahasa Arab peneliti memberi post test, tes ini untuk mengetahui sejauh mana penerapan Integrated System dalam peningkatan prestasi belajar. Dalam hal ini, peran peneliti kemudian merangkap sebagai pengajar atas rekomendasi dari guru mata pelajaran bahasa Arab, sedangkan guru menjadi kolaborator dan observer.

b. Pelaksanaan

Peneliti melaksanakan tindakan penelitian siklus pertama sebanyak satu pertemuan, yaitu pertemuan pada hari Senin, 04 Maret 2019. Subjek Penelitian yaitu siswa kelas XI IPA dan XI IPS, diberi tindakan penelitian dalam pembelajaran secara bergilir sesuai jadwal mata pelajaran bahasa Arab di hari senin, dimulai dengan kelas XI IPS terlebih dahulu kemudian kelas XI IPA pada jam berikutnya dengan durasi waktu masing-masing kelas yaitu 1 x 90 menit, pada faktanya kelas XI IPA dijadwalkan pada hari Jum'at jam ke-dua maka dari itu, peneliti telah berkoordinasi dengan kepala Madrasah dan guru terkait yang mengajar pada hari Senin di kelas IPA untuk tukar jam mengajar ke hari Jum'at. Pada pertemuan siklus I ini tingkat kehadiran siswa 100 \% baik IPA maupun IPS.

Kegiatan ini dilakukan di ruang kelas XI IPA dan XI IPS. Selama tindakan penelitian berlangsung, Guru bahasa Arab bertugas sebagai kolaborator yaitu mengawasi, mengamati dan memposisikan diri sebagai pemberi opini ataupun masukan bilamana perlu dalam suatu pembahasan materi yang disampaikna penelilti. Berikut adalah hasil observasi peneliti terhadap guru bahasa Arab dalam penerapan pendekatan Integrated System dalam pembelajaran bahasa Arab di kelas.

1. Kegiatan Pendahuluan: ${ }^{21}$

Guru mengucapkan salam dan mengatur kelas sebelum memulai pembelajaran dengan keadaan kurang kondusif siswa cenderung ramai.

Guru menanyakan kembali materi yang lalu, sebelum melanjutkan pembelajaran. 
- Guru tidak menjelaskan kompetensi yang akan dicapai dalam pembelajaran.

2. Kegiatan Inti:

- Gurumenjelaskanmateripelajarandenganmenggunakanpendekatan Integrated System, menyampaikan materi امال المراهقين mengaitkan dengan contoh dalam kehidupan sehari-hari, menanyakan kepada siswa tentang materi yang belum difahami siswa setelah dijelaskan akan tetapi guru tidak mengajukan pertanyaan contoh yang terkait tema pada siswa.

- $\quad$ Siswa mencari jawaban dalam buku teks bahasa Arab atas pertanyaan yang diajukan guru dan tidak ada pembahasan tentang jawaban siswa dan juga siswa dan guru tidak bertanggungjawab atas jawaban yang telah ditemukan oleh siswa.

3. Konfirmasi:

- Guru tidak memberikan umpan balik terhadap proses dan hasil diskusi peserta didik untuk meluruskan kesimpulan-kesimpulan diskusi yang kurang tepat.

4. Kegiatan Akhir:

- Guru bersama-sama dengan peserta didik menyimpulkan pembelajaran

- Siswa tidak mengerjakan tugas dan membahas bersama-sama dengan guru

- Guru mengakhiri pembelajaran secara islami.

\section{c. Observasi}

Hasil observasi yang diperoleh peneliti melalui lembar observasi berupa observasi minat siswa berdasarkan hasil dari penelitian siklus I mengenai tingkat minat siswa dalam mengikuti kegiatan pembelajaran bahasa Arab, dengan cara men-ceklist $(\sqrt{ })$ bobot skor pada setiap pernyataan, dapat diketahui bahwa siswa menunjukkan respon yang baik ketika peneliti memulai kegiatan belajar-mengajar sejak apersepsi hingga akhir pelajaran, karena bagi mereka kegiatan pembelajaran bahasa Arab belum pernah disampaikan dalam bentuk diskusi, melainkan hanya materi teori saja. Dihasilkan total pemerolehan $\left(\sum x=32\right.$ ), jumlah skor maksimal $\mathrm{N}$ $=60$. Maka diperoleh prosentase:

$$
\begin{aligned}
\% & ={ }^{\frac{\sum x}{N}} \times 100 \% \\
\% & =32 / 60 \times 100 \% \\
& =53,3 \%
\end{aligned}
$$


Berdasarkan hasil prosentase di atas, observasi siklus I siswa adalah 53,3\%, maka minat siswa tergolong Cukup Berminat.

Kategori Nilai

0-20\% : Sangat Tidak Berminat

$21-40 \% \quad$ : Kurang Berminat

41-60\% : Cukup Berminat

$61-80 \%$ : Berminat

81-100\% : Sangat Berminat

d. Evaluasi dan Refleksi

Selama pembelajaran bahasa Arab pada siklus pertama, peneliti menemukan beberapa kendala terkait dengan penerapan pendekatan Integrated System yaitu:

1) Keterbatasan waktu serta bahasa penyampaian yang terlalu panjang, sehingga cukup mengurangi keefektifan mengajar dan berdampak pada minat siswa yang rata-rata kesulitan mengolah gagasan selama pelajaran bahasa Arab.

2) Efektivitas penggunaan waktu untuk kegiatan pembelajaran bahasa Arab sedikit tersita oleh faktor fasilitas yang mendukung di dalam kelas seperti gambar-gambar, audio (rekaman) terkait materi pelajaran dan juga waktu untuk berganti ruang antara kelas XI IPA dengan XI IPS.

3) Suasana kelas pada tiap persiapan awal pembelajaran kurang kondusif karena siswa perlu dikondisikan supaya tenang dan duduk rapi.

4) Penerapan materi RPP terkait dengan alokasi waktu yang ada yaitu $1 \mathrm{x}$ 90 menit untuk tiap kelasnya dirasakan oleh peneliti masih kurang efektif untuk jenjang SMA/MA, sehingga yang terjadi adalah tidak konsistennya penerapan pendekatan Integrated System dalam RPP yang dipakai. Peneliti kesulitan untuk menyesuaikan penyampaian materi dan proses pembelajaran dengan waktu yang tersedia.

Berdasarkan kendala-kendala di atas, peneliti berupaya untuk melanjutkan penelitian pelaksanaan siklus II sebagai dasar perbaikan dan refleksi dengan langkahlangkah sebagai berikut:

1) Merancang pembelajaran sesuai dengan asas pendekatan Integrated System dengan metode Aural-Oral dengan mempertimbangkan alokasi waktu yang tersedia yaitu 90 menit.

2) Meminta bantuan guru atau kolaborator untuk melakukan pengkondisian siswa di kelas, sehingga siswa dapat terkontrol dan segera menuju ke ruang kelas. 
3) Mengupayakan apersepsi dan diskusi kelompok yang lebih menarik dengan melibatkan media-media yang tersedia.

Peneliti juga mengukur keberhasilan siswa dalam mata pelajaran bahasa Arab dengan menggunakan tes, yaitu pre test dan post test. Dimana pre test dilakukan sebelum tindakan pada siklus I, kemudian setelah pembelajaran selesai peneliti melakukan post test. pre test dan post test digunakan sebagai perbandingan perubahan yang terjadi antara sebelum dan sesudan dilakukan tindakan. Berikut adalah hasil pre test dan post test kelas XI IPA dan IPS.

Berdasarkan hasil tes pada siklus I, didapatkan bahwa rata-rata nilai pre test kelas XI IPA adalah 7,08 dan post test 8,92 . Pada pre test dan post test siklus I ini menunjukkan bahwa adanya kenaikan prestasi belajar siswa kelas XI IPA pada mata pelajaran bahasa Arab. Dan didaptkan bahwa rata-rata nilai pre test kelas XI IPS adalah 6,75 dan post test 8,3 . Pada pre test dan post test siklus I ini menunjukkan bahwa adanya kenaikan prestasi belajar siswa kelas XI IPS pada mata pelajaran bahasa Arab.

\section{Pelaksanaan Tindakan Siklus II}

Sebelumnya peneliti telah mengolah hasil observasi minat dan evaluasi belajar siswa siklus I, kemudian peneliti melaksanakan pembelajaran Siklus II sebagai dasar perbaikan pembelajaran bahasa Arab dengan menggunakan pendekatan Integrated System.

a. Perencanaan

Peneliti merencanakan desain pembelajaran sesuai dengan pendekatan Integrated System dengan mempertimbangkan alokasi waktu yang tersedia yaitu 90 menit. Pada tahap ini, peneliti telah mempersiapkan perangkat pembelajaran yang hampir sama dengan siklus I, terdiri RPP bahasa Arab materig الصحة الرعايه الصحيه, dengan beberapa penyesuaian terhadap efektivitas waktu dan menerapkan asas-asas pendekatan Integrated System, lembar observasi berupa lembar skala minat berikut pedoman penskorannya.

b. Pelaksanaan

Peneliti melaksanakan penelitian siklus kedua pada hariSenin, 11 Maret 2019. Sehubungan dengan refleksi dari hasil tindakan penelitian pada siklus pertama, peneliti mendapatkan bantuan dari guru bahasa Arab (kolaborator) yaitu telah mengkondisikan siswa untuk siap menerima materi sebelum 5 menit dimulai. Sehingga, peneliti dapat memaksimalkan waktu yang tersedia. Kemudian dilakukan berupa menirukan lafal apa yang disampaikan oleh guru dan siswa mengulangi lafal tersebut, setelah itu guru membacakan beberapa mufrodat untuk diulangi dan dihafal. Berikut adalah hasil observasipeneliti terhadap guru siklus II pada pembelajaran bahasa Arab dengan pendekatan Integrated System di kelas. 
1. Kegiatan Pendahuluan:

- Guru mengucapkan salam dan mengatur kelas sebelum memulai pembelajaran dengan keadaan kurang kondusif siswa cenderung ramai.

- Guru menanyakan kembali materi yang lalu, sebelum melanjutkan pembelajaran.

- Guru tidak menjelaskan kompetensi yang akan dicapai dalam pembelajaran.

2. Kegiatan Inti:

- Guru menjelaskan materi الصحـة والرعاية الصحية (kesehatan dan menjaga kesehatan)

- Siswa mendengarkan penjelasan guru tentang الصحة والرعاية الصحية

- Guru menanyakan kepada siswa tentang materi yang belum difahami siswa setelah dijelaskan

- Guru meminta siswa untuk mengulang kata yang diucapkan oleh guru.

- Guru membagi siswa menjadi kelompok-kelompok kecil.

- Siswa tidak melakukan pencarian informasi mengenai pertanyaan yang diberikan oleh guru dan mengulang-ulang kata mufrodat sampai hafal.

- Siswa tidak menyampaikan hasil pencarian informasi yang dilakukan, kemudian menyebutkannya sampai hafal.

- Siswa dan guru bertanggungjawab atas jawaban yang telah ditemukan oleh siswa.

- Guru memberikan umpan balik terhadap proses dan hasil diskusi peserta didik untuk meluruskan kesimpulan-kesimpulan diskusi yang kurang tepat.

3. Kegiatan Akhir:

- Guru tidak menyampaikan kesimpulan materi pelajaran.

- Guru meminta siswa untuk mengulang-ulang mufrodat yang disampaikan oleh guru.

- Guru bersama siswa merefleksi proses pembelajaran yang telah berlangsung, meliputi: kelemahan dan kelebihan, perasaan dan kesulitan yang dihadapi siswa serta pemberian tugas di rumah.

- Guru mengakhiri pembelajaran secara islami. 
c. Observasi

Pada siklus II jumlah siswa yang hadir sama seperti sebelumnya yaitu 33 siswa (IPA dan IPS) atau dikatakan nihil. Hasil observasi yang diperoleh peneliti melalui lembar observasi berdasarkan hasil dari penelitian siklus II mengenai tingkat minat siswa dalam mengikuti kegiatan pembelajaran bahasa Arab, dengan cara men-ceklist $\left({ }^{2}\right)$ bobot skor pada setiap pernyataan, dapat diketahui bahwa siswa menunjukkan respon yang baik ketika peneliti memulai kegiatan belajar-mengajar sejak apersepsi hingga akhir pelajaran karena bagi mereka kegiatan pembelajaran bahasa Arab dengan cara menirukan apa yang diucapkan oleh guru kemudain bersama-sama menirukan kembali apa yang diucapkan oleh guru dan menghafal mufrodat sampai benar-benar hafal. Dihasilkan total pemerolehan $\left(\sum x=45\right.$, jumlah skor maksimal $N=60$. Maka diperoleh prosentase:

$$
\begin{array}{rl}
\%={ }^{\frac{\sum x}{N}} \mathrm{X} & 100 \% \\
\% & =45 / 60 \times 100 \% \\
= & 75 \%
\end{array}
$$

Berdasarkan hasil prosentase di atas, observasi siklus II siswa adalah $75 \%$, maka minat siswa tergolong Berminat.

Kategori Nilai

0-20\% : Sangat Tidak Berminat

$21-40 \% \quad$ : Kurang Berminat

41-60\% : Cukup Berminat

$61-80 \%$ : Berminat

$81-100 \% \quad$ : Sangat Berminat

d. Evaluasi dan Refleksi

Pada proses belajar mengajar bahas Arab di kelas XI pada siklus II, peneliti memperoleh hasil yang cukup signifikan antara lain sebagai berikut:

1) Alokasi waktu yang ada dengan penyampaian materi oleh peneliti dapat dimaksimalkan sesuai dengan pembenahan isi materi yang dilakukan setelah siklus I.

2) Suasana pembelajaran sejak persiapan hingga pelaksanaan cukup kondusif karena siswa sudah mampu mengkondisikan diri untuk tenang dan duduk rapi dengan dibantu oleh guru dan juga karena guru bahasa Arab telah mempersiapkan kondisi siswa yang kondusif sebelum 5 menit pembelajaran dimulai.

3) Pemakaian alokasi waktu yang ada yaitu 1 x 90 menit dan dikondisikan dengan cara 5 menit sebelum melaksanakan pembelajaaran siswa telah 
kondusif dan siap menerima pelajaran, terkait dengan penerapan materi dalam RPP mata pelajaran bahasa Arab cukup efektif bagi peneliti sendiri. Peneliti perlu lebih teliti dalam memilih bahan diskusi yang lebih tepat untuk menyesuaikan antara penyampaian materi dan waktu yang tersedia.

4) Implementasi pendekatan Integrated System pada siswa kelas XI MA NU Miftahul Ulum Margasari membawa pengalaman baru kepada siswa kelas XI IPA maupun XI IPS, karena penguasaan kosakata (mufrodat) bahasa Arab menjadi lebih mudah dan siswa lebih aktif bertanya tentang makna dari kosakata yang tidak dipahami.

Dari pembahasan refleksi di atas, ditemukan juga selama pembelajaran bahasa Arab pada siklus II, peneliti memperoleh kendala terkait penerapan pendekatan Integrated System antara lain:

1) Siswa kesulitan untuk membayangkan hal-hal apa saja yang harus siwa lakukan agar sesuai dengan tujuan, hal ini dikarenakan guru dan peneliti tidak menjelaskannya kompetensi yang akan dicapai dalam pembelajaran.

2) Siswa tidak melakukan pencarian informasi mengenai pertanyaan yang diberikan oleh guru dan mengulang-ulang kata mufrodat sampai hafal, dikarenakan peneliti kurang menekankan pada satu mufrodat yang harus dihafal.

3) Siswa kurang memahami, mungkin dikarenakan peneliti tidak menyampaikan kesimpulan materi pelajaran yang dianggap sulit oleh siswa.

Melihat kondisi ini, peneliti melanjutkan penelitian pada pelaksanaan siklus III sebagai dasar perbaikan dengan langkah-langkah sebagai berikut:

1) Merancang pembelajaran sesuai dengan pendekatan Integrated System secara lebih kreatif dengan mempertimbangkan penjelasan kompetensi yang akakn dicapai dalam pembelajaran.

2) Mencari informasi-informasi tentang mufrodat pada materi pelajaran terlebih dahulu sebelum diberikan kepada siswa agar peneliti lebih menekankan pada satu mufrodat yang harus dihafal.

3) Mengupayakan menyimpulkan materi pelajaran yang dianggap sulit oleh siswa agar lebih mudah dipahami oleh siswa.

Peneliti juga mengukur keberhasilan siswa pada mata pelajaran bahasa Arab materi tentang الصحة والرعاية الصحية (kesehatan dan menjaga kesehatan) dengan menggunakan tes, yaitu pre test dan post test. Dimana pre test dilakukan sebelum tindakan pada siklus II, kemudian setelah pembelajaran selesai peneliti melakukan post test. pre test dan post test digunakan sebagai perbandingan perubahan yang 
terjadi antara sebelum dan sesudan dilakukan tindakan. Berikut adalah hasil pre test dan post test kelas XI IPA dan IPS.

Berdasarkan hasil penilaian tes didapatkan bahwa rata-rata nilai pre test kelas XI IPA adalah 7,77 dan post test 8,76. Pada pre test dan post test siklus II ini menunjukkan bahwa adanya kenaikan prestasi belajar siswa kelas XI IPA pada mata pelajaran bahasa Arab. Dan didapatkan bahwa rata-rata nilai pre test kelas XI IPS adalah 7 dan post test 8,2 . Pada pre test dan post test siklus II ini menunjukkan bahwa adanya kenaikan prestasi belajar siswa kelas XI IPS pada mata pelajaran bahasa Arab.

\section{Pelaksanaan Tindakan Siklus III}

Setelah selesai mengolah hasil observasi dan evaluasi hasil siklus I dan II, kemudian peneliti melanjutkan ke tahap pembelajaran siklus III sebagai dasar perbaikan pembelajaran bahasa Arab dengan pendekatan Integrated System.

\section{a. Perencanaan}

Seperti biasa, sebelum peneliti melaksanakan perbaikan pembelajaran pada siklus III, peneliti merencanakan desain pembelajaran sesuai pendekatan Integrated System secara kreatif dengan menjelaskan kompetensi yang akan dicapai dalam pembelajaran, penekanan pada satu mufrodat yang harus dihafal dam menyampaikan kesimpulan materi pelajaran yang dianggap sulit oleh siswa. Pada tahap ini, peneliti telah mempersiapkan perangkat pembelajaran (RPP) dengan materi النظافة في الإسـلام, dengan menyusun kompetensi yang akan dicapai dalam pembelajaran sebelum disampaikan kepada siswa, penekanan pada satu mufrodat yang harus dihafal dan kesimpulan materi pelajaran yang dianggap sulit oleh siswa. lembar observasi berupa lembar skala minat berikut pedoman penskorannya, dan angket minat belajar siswa dan melaksanakan pre test dan post test dengan 50 butir soal mencakup materi dari siklus I, II dan III. Tes ini bertujuan untuk mengetahui prestasi atau capaian hasil belajar siswa selama 3 siklus dalam penerapan Integrated System.

\section{b. Pelaksanaan}

Peneliti melaksanakan penelitian siklus kedua pada hariJum'at, 15 Maret 2019. Sehubungan dengan refleksi dari hasil tindakan penelitian pada siklus pertama, peneliti dan kolaborator berupaya menyampaikan kompetensi yang akan dicapai dalam pembelajaran kepada siswa, menekankan siswa dalam menghafal satu mufrodat sampai hafal sebelum melanjut ke hafalan lain, dan menyimpulkan materi pelajaran yang dianggap sulit oleh siswa. Berikut adalah hasil observasipeneliti terhadap guru siklus III pada pembelajaran bahasa Arab dengan pendekatan Integrated System di kelas.

Kegiatan Pendahuluan:

Guru mengucapkan salam dan mengatur kelas sebelum memulai pembelajaran dengan keadaan kurang kondusif siswa cenderung ramai. 
- Guru menanyakan kembali materi yang lalu, sebelum melanjutkan pembelajaran.

- Guru menjelaskan kompetensi yang akan dicapai dalam pembelajaran

b Kegiatan Inti:

Guru menjelaskan materi النظافة في الإسـلام (Kebersihan dalam Islam)

- Siswa mendengarkan penjelasan guru tentang $\quad$ النظافة في الإسـلام

- Guru menanyakan kepada siswa tentang materi yang belum difahami siswa setelah dijelaskan

- Guru melakukan tanya jawab tentang tarkib نعت و منعت dan contoh نعت و منعت (na'at man’ut) dalam sebuah kalimat.

- Siswa menyampaikan hasil pencarian informasi yang dilakukan, kemudian menyebutkannya sampai hafal.

- Siswa dan guru bertanggungjawab atas jawaban yang telah ditemukan oleh siswa

- Perwakilan kelompok mempresentasikan materi $\quad$ النظافة في الإسـلام (Kebersihan dalam Agama Islam) dengan cara membaca sebuah kalimat tentang النظافة في الإسـلام di depan kelas, kemudian kelompok yang lain mengulangi perkataanya.

- Setiap kelompok yang masih salah dalam pelafalan disuruh mengulangi terus menerus sampai tepat dan sesuai.

- Guru memberikan umpan balik terhadap proses dan hasil diskusi peserta didik untuk meluruskan kesimpulan-kesimpulan diskusi yang kurang tepat

- Guru memberi reward dan reinforcerment pada siswa yangmenjawab dan menyampaikan pendapat.

c Kegiatan Akhir:

a. Guru menyampaikan kesimpulan materi pelajaran.

b. Guru meminta siswa untuk mengulang-ulang mufrodat yang disampaikan oleh guru.

c. Sebelum mengakhiri pembelajaran guru memberikan tugas rumah النظافة في kepada siswa untuk mengerjakan latihan soal tentang pada buku teks bahasa Arab kelas XI.

d. Guru mengakhiri pembelajaran secara islami. 
c. Observasi

Hasil observasi yang diperoleh peneliti melalui lembar observasi berdasarkan hasil dari penelitian siklus III mengenai tingkat minat siswa dalam mengikuti kegiatan pembelajaran bahasa Arab, dengan cara men-ceklist ( ${ }^{\sqrt{ }}$ ) bobot skor pada setiap pernyataan, dapat diketahui bahwa siswa menunjukkan respon yang lebih baik, siswa antusias ketika peneliti memulai kegiatan belajar-mengajar sejak apersepsi hingga akhir pelajaran karena bagi mereka kegiatan pembelajaran bahasa Arab dengan guru menyampaikan kompetensi yang dicapai dalam pembelajaran, siswa lebih mengetahui apa saja yang harus dicapai agar dapat lulus dalam mata pelajaran bahasa Arab. Dihasilkan total pemerolehan ( $\sum x=47$, jumlah skor maksimal $\mathrm{N}=60$. Maka diperoleh prosentase:

$$
\begin{aligned}
\% & ={ }^{N} \times 100 \% \\
\% & =47 / 60 \times 100 \% \\
& =78,3 \%
\end{aligned}
$$

Diperoleh hasil prosentase observasi siklus III siswa adalah 78,3\%, maka minat siswa tergolong berminat.

d. Angket Minat Siswa

Hasil angket yang peneliti peroleh pada siklus III melalui lembar angket siswa yang peneliti sebar kepada 33 siswa kelas XI (IPA dan IPS) dalam proses pembelajaran bahasa Arab setelah menggunakan pendekatan Integrated System. Angkat ini adalah sebagai tolak ukur dari pandangan subjek penelitian (siswa) setelah mengikuti kegiatan pembelajaran bahasa Arab dengan menggunakan pendekatan Integrated System.Rekap skor yang diberikan terhadap pernyataanpernyataan dalam angket minat siswa dilihat dengan ketentuan sebagai berikut:

a. Untuk pernyataan dengan kriteria positif: $1=$ Sangat Tidak Setuju, $2=$ Tidak Setuju, $3=$ Ragu-ragu, $4=$ Setuju, $5=$ Sangat Setuju .

b. Untuk pernyataan dengan kriteria negatif: 1=Sangat Tidak Setuju, 2=Tidak Setuju, $3=$ Ragu-ragu, $4=$ Setuju, $5=$ Sangat Setuju.

c. Menghitung skor rata-rata gabungan dari kriteria positif dan negatif tiap kondisi.

Berikut adalah hasil skor rata-rata kriteria positif, negative dan rata-rata gabungan dri kriteria positif dan negatif berdasarkan angket minat belajar siswa

1. Skor rata-rata kriteria positif

Jumlah siswa pada kelas XI adalah 33 siswa, butir item seluruhnya ada 33 item dengan kriteria positif sebanyak 25 item dan negatif sebanyak 8 item. Sedangkan maksimal skor per item sebanyak $(N=(33 \times 5=165))$. jumlah total skor maksimal sebanyak $(165 \times 25=4125)$. Berdasarkan tabel minat 
jumlah skor siswa yang menjawab dengan kriteria positif sebanyak xi $=$ $\tilde{x}=\frac{\sum_{i=1}^{n} x i \text { Maka dapat diperoleh skor rata-rata: }}{N}$

$\mathrm{X}=3766 / 165=22,82$

2. Skor rata-rata kriteria negatif

Jumlah item dengan kriteria negatif sebanyak 8 item.Sedangkan jumlah siswa sebanyak 33 siswa, jumlah maksimal skor per item sebanyak (33 x $5=165)$.jumlah total skor negatif maksimal sebanyak $(\mathrm{N}=(165 \times 8=$ 1320)). Berdasarkan tabel minat jumlah skor siswa yang menjawab dengan $\tilde{x}=\frac{\sum_{i=1}^{n} x i}{N}$ negatif sebanyak $x i=473$. Maka dapat diperoleh skor rata-rata:

$X=1320 / 473=2,79$

3. Skor rata-rata gabungan

Dari skor rata-rata kriteria positif dan negatif 33 item (25 item positif dan 8 item negatif) yang telah diperoleh di atas, maka skor rata-rata gabungannya adalah (kriteria positif + kriteria negatif $)=(22,82+2,79=$ 25,61). 25,61 adalah rata-rata gabungan dari kriteria positif dan negatif, jika diprosentasikan menjadi:

$$
\begin{aligned}
\% & =\frac{\sum x i}{\sum N} \mathrm{X} 100 \% \\
\% & =25,61 / 33 \times 100 \% \\
\% & =77,6 \%
\end{aligned}
$$

Dari hasil prosentase di atas, dapat dikategorikan bahwa minat belajar bahasa Arab siswa kelas XI adalah Kuat (Berminat) sebanyak 77,6\%.

e. Evaluasi dan Refleksi

Selama pembelajaran bahasa Arab pada siklus III, peneliti memperoleh hasil yang cukup signifikan antara lain sebagai berikut:

1) Peneliti dan kolaborator menyampaikan kompetensi yang hendak dicapai dalam pembelajaran, sehingga membuat siswa mengetahui kompetensikompetensi apa saja yang perlu diupayakan agar mencapai tujuan pembelajaran.

2) Suasana pembelajaran sejak persiapan hingga pelaksanaan kondusif, dan siswa antusias dalam menerima pelajaran.

3) Siswa dapat menghafal lebih baik daripada siklus sebelumnya, karena penekanan pada satu mufrodat hingga benar-benar hafal sebelum menghafal ke mufrodat selanjutnya. 
4) Siswa dapat memahami kesulitan yang dialami pada kegiatan pembelajaran setelah Guru menyimpulkan materi pembelajaran yang dianggap sulit oleh siswa.

\section{f. Hasil Tes Siswa Siklus III}

Pengukuran keberhasilan tindakan siklus III melalui Tes Kemampuan Bahasa Arab yang telah peneliti susun sebanyak 50 butir soal dengan mencakup materi pada siklus I, II dan III.Berikut adalah hasil pre test dan post test kelas XI IPA dan IPS.

Berdasarkan hasil penilaian pada siklus III diperoleh bahwa rata-rata pre test (pra tindakan) siswa kelas XI adalah 71,5 dengan 18 siswa atau 54,5\% dinyatakan lulus dan 15 siswa atau 45,5\% gagal, dan rata-rata post test (setelah tindakan) siswa kelas XI adalah 75,7 dengan 29 siswa atau 87,9\% dinyatakan lulus dan 4 siswa atau $12,1 \%$ gagal. Hal ini membuktikan bahwa prestasi belajar siswa kelas XI meningkat.

\section{E. Penutup}

All in One System atau Integrated System adalah sistem atau susunan yang digabungkan menjadi satu kesatuan yang utuh tidak terpisah-pisahkan dan pembelajaran bahasa Arab berhubungan erat dengan yang lainnya bukan dibagi atas beberapa bagianPendekatan ini berasumsi pengajaran Bahasa harus dimulai dengan mengajarkan kemahiran menyimak atau mendengarkan bunyi bahasa dalam kata atau kalimat, dan melatih pengucapannnya sebelum pelajaran membaca dan menulis dilakukan. Jadi, urutan pengajaran kemahiran berbahasa adalah menyimak (al-istima', listening), berbicara (alkalam, speaking), membaca (al-qira'ah, reading), dan menulis (kitabah, writing).

Dari hasil penelitian ditemukan peningkatan minat belajar siswa secara signifikan dari pra tindakan sampai dengan pelaksanaan tindakan siklus I, II, dan siklus III.Dihasilkan bahwa pada pra tindakan minat siswa kurang berminat sebanyak 40\%, kemudian setelah pelaksanaan tindakan pada siklus I meningkat menjadi cukup berminat sebanyak 53,30\% (naik 13,3\%), pada siklus II meningkat menjadi Berminat 75\% (naik 21,7\%), dan pada siklus III mengalami keajegan degan kategori Berminat namun prosentasenya meningkat menjadi 78,30\% (naik 3,3\%). Berdasarkan Angket Minat Siswa, dari skor rata-rata kriteria positif dan negatif 33 item (25 item positif dan 8 item negatif) yang telah diperoleh, maka skor rata-rata gabungannya adalah (kriteria positif + kriteria negatif $)=(22,82+2,79=25,61) .25,61$ adalah rata-rata gabungan dari kriteria positif dan negatif, jika diprosentasikan menjadi 77,6\%, maka minat belajar bahasa Arab siswa kelas IX kuat (berminat)sebanyak 77,6\%.Implementasi Integrated System membawa dampak positif terhadap prestasi belajar siswa kelas IX. Peneliti menggunakan pre test dan post test pada setiap siklus I, II dan III. Hasil prestasi belajar menunjukkan bahwa dari siklus I, II dan III nilai mata pelajaran bahasa Arab siswa kelas XI IPA dan IPS di atas rata-rata KKM. Jadi dapat disimpulkan bahwa prestasi belajar siswa meningkat dengan rata-rata 75,7 di atas nilai KKM 67. 
El-Tsaqafah: Jurnal Jurusan PBA, Vol. 18, No.2, Desember 2019

\section{DAFTAR PUSTAKA}

Akbar, Sa'dun. 2008. Penelitian Tindakan Kelas (Filosofi, Metodologi dan Implementasinya). Malang: Surya Pena Gemilang.

al-Hafid,Radhi. 1993. PengembanganMateridanMetodePengajaranBahasaArab. Ujungpandang: Berkah.

Arsyad, Azhar. Bahasa Arab dan Metode Pengajaran. Yogyakarta: Pustaka Pelajar.

Bafadal, Ibrahim. 2006. Pengelolaan Perpustakaan Sekolah. Jakarta: Bumi Aksara.

Hurlock. 1990. Perkembangan Anak, Jilid II, Penerjemah: Meitasari Tjandrasa. Jakarta: Erlangga.

Madjidi, Busyairi. 1994. Metodologi Pengajaran Bahasa Arab Penerapan Audio Lingual Method dalam All In One System. Yogyakarta: Sumbangsih Offset.

Mulyasa, H. E. 2014. Pengembangan Implementasi Kurikulum 2013. Cet. Ke-5. Bandung: PT Remaja Rosdakarya.

Muna, Wa. 2011. Metodologi Pembelajaran Bahasa Arab.Cet. I. Yogyakarta: Teras.

Muslich, Mansur. 2009. Melaksanakan PTK Itu Mudah.Jakarta: Bumi Aksara.

Nata, Abuddin. 2011. Studi Islam Komprehensif.Cet. Ke-I. Jakarta: Kencana.

Rusydi Rasyid, Muhammad. "ALL IN ONE SYSTEM (Pendekatan dan Prinsip Psikologis Pengajaran Bahasa Arab Terintegrasi)", LENTERA PENDIDIKAN, Vol. 12, No. 1 Juni 2009: 33-45

Suharsimi, dkk. 2008. Penelitian Tindakan Kelas. Jakarta: Bumi Aksara.

Sumardi, Mulyanto. 1974. Pengajaran bahasa Asing: sebuah tinjauan dari segi metodologis. Cet. I. Jakarta: Bulan Bintang,.

T Gilkey, Herbert."New Air Heating Methods", New methods of heating buildings: a research correlation conference conducted by the Building Research Institute, Division of Engineering and Industrial Research, as one of the programs of the BRI fall conferences, November 1959., (Washington: National Research Council (U.S.). Building Research Institute.

Tauhid, Abu. 1990. Beberapa Aspek Pendidikan Islam. Yogyakarta: FTY.

Timoty, Brilliant dan Fadly, Hasan.Kamus Lengkap Inggris-Indonesia Indonesia-Inggris. Jakarta: Grafika Mulia.

Undang-Undang No. 14 Tahun 2005 Tentang Pendidik dan Dosen, Pasal 1 ayat 1.

Zaenuddin, Radliyah, et. al. 2005.Metodologi dan Strategi Alternatif Pembelajaran Bahasa Arab.Yogyakarta: Pustaka Rihlah Group. 